\title{
エンジニアリングプラスチックの ポリマーアロイ
}

伊睪 槙 一*

1.はじめに

エンジニアリングプラスチック(以下ェンプラ といら）は，大体 $100 〜 200^{\circ} \mathrm{C}$ 実用耐熱温度を示 するのを指し，数多くの材料が上市され，おのお の用途にあっだ゙レード展開によって広く利用さ れている.エンプラが実用に供されている分野, 特に自動車用途，電気・電子用途などでは，材料 に対する要求性能は, 上り高度化, 多様化の㑯向 を示し，単一のポリマーでの対応には限界がある 場合が多くなってきている．今回は，これらのェ ンブラのポリマーアロイ化による展開の現状の一 端を釈介する。

プラスチックは，図1に大略を示すように，実 用耐熱温度 (通常, UL の長期使用温度をインデ ックスとしている) と価格との間には相関があり， 高温での長い時間の信頼に耐党る材料は，それだ け高いコストがかかることがわかる11.

エンプラの分野では, 新規樹脂開発のリスクが 大きく，ここ当分ニニークな材料開発は少なく， 既存のエンプラやはん用プラを応用したポリマー アロイ化が主流になると考えられている。

ポリマーアロイ化は, 1946年の ABS 樹脂から 始まるが，ポリフェニレンエーテルとポリスチレ ン(PS) とのアロイ化による变性 PPEが，本格的 な意味での異種ポリマーによるアロイとして著名 である2). PC/ABS，PC/PBT，PA/PPE，PBT/ PET, PA/ポリオレフィンなどが相次いで市場に 登場し, 現在では, あらゆるポリマー同士のフロ イ化が検討され，そのらちの相当数が実用に供さ れている3).

特に, この十年余りの間に, 非相溶なポリマー を混合した分散系に関する研究が大きく進展して おり, 同時にボリマーが相互に溶けあ5系の研究

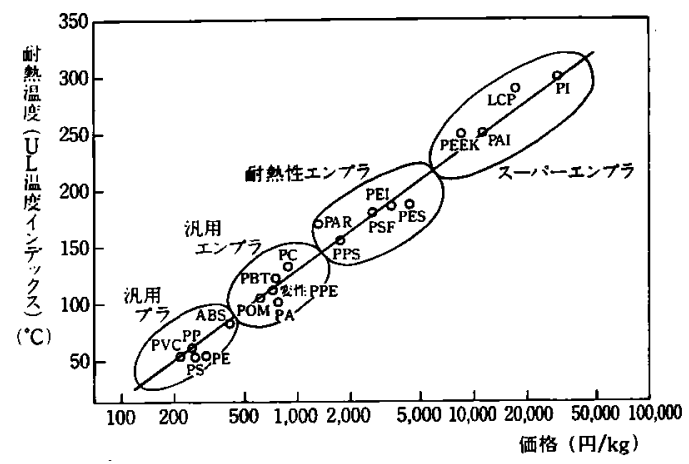

図 1 実用耐熱と価格1)

の進展る著しい4).

工業的な実用性の観点からみた場合には，非相 溶なボリマーの組合せで，おのおのの特徽(長所) を活かした材料を開発することが大切な狙いどこ ろとなる1). 図 2 に示す三種類の技術が相互に影 響しつつ現在のポリマーアロイ開発は進んでい る、特許にあらわれる特徵の一つに，基礎解析技 術を基盤に置いた材料の定義とその作用の記載が 多くなっていることが挙げられる。

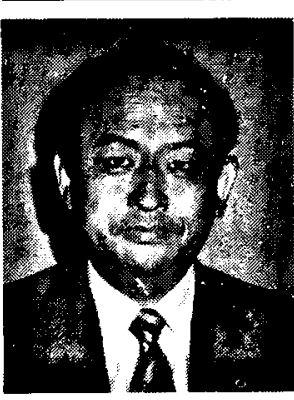

*旭化成工業株式会社樹脂技 術開発総部 ( 県川崎市川崎区夜光1-3-1) 部長. 工博. 昭和 34 年, 東 京工菜大学理工学部卒業. 35年, 旭化成工業(株)入社. 43年〜 57年, 旭多ウ(佅出向. 61年より現職. 尃門は高分 子化学. 研究テーマはポリ マーの夜合化による新機能 材料の開発.

〈趣味〉ハドントン, ハ スケットなどスポーツ. 


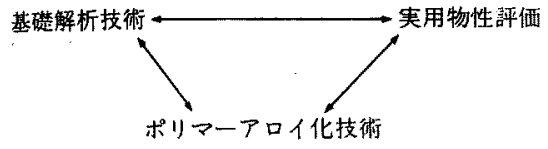

図 2 ポリマーアロイの実用化への三要素1)

\section{2. 全般的状 況}

今年の 4 月11日から14日にかけて，日本では初 めてのプラスチック加工国際学会 (PPS-5)が京都 で開催された。 この学会で，ポリマーアロイは一 つのシンポジウムが組まれ，ポスターセッション とあわせると，40件あまりの発表があり盛況であ った，時を同じくして，アメリカでは，第 1 回の 国際コンファレンス「Compalloy'89」がニューオ ルリーンズで開かれた。 この会議の命名は，ポリ マーフロイのキーテクノロジーである「コンパテ イビライザー技術」と「リアクティブプロセッシ ング技術」とを組合せたるのであり，世界のポリ マーアロイ研究者, 開発者が約 150 人集まった。 Compalloy'89は民間会社，特に材料メ一カ一， コ ンパティビラィザーメーカー，機械メーカーから の発表が汪とんどであったのが特徵といえる。

\section{1 市場動向}

エンプラを中心とするポリマーアロイの需要推 移を表 1 にまとめた。量的には，PPE/PS が50\%

\begin{tabular}{|c|c|c|c|}
\hline ボリマーアロイ種 & 61年 & 62年 & 63年 \\
\hline ポリアミド/ポリオレフィン系 & 1,500 & 1,800 & 2,100 \\
\hline 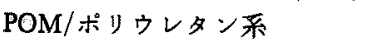 & 900 & 1,150 & 1,250 \\
\hline PC/ABS 系 & 6,810 & 7,790 & 8,900 \\
\hline $\mathrm{PC} /$ ポリエステル系 & 2,100 & 2,400 & 2,600 \\
\hline PC/PS 系 & 400 & 480 & 500 \\
\hline PPE/PS 系 & 49,500 & 57,500 & 64,000 \\
\hline $\mathrm{PPE} / \mathrm{PA}$ 系 & 300 & 320 & 350 \\
\hline PBT/PET 系 & 800 & 1,000 & 1,200 \\
\hline ボリエステルエラストマー系 & 3,310 & 3,520 & 3,700 \\
\hline $\begin{array}{l}\text { ボリアミドェラストマー系 } \\
\text { (はん用ポリマー系) }\end{array}$ & 600 & 705 & 720 \\
\hline $\mathrm{ABS} / \mathrm{PVC}$ & 20,300 & 21,800 & 23,700 \\
\hline PS/PMMA & 4,200 & 4,800 & 5,100 \\
\hline PS/MAH コポリマー & 3,300 & 3,600 & 3,800 \\
\hline 変性イミド化ポリマー & 500 & 1,060 & 1,200 \\
\hline $\begin{array}{l}\text { 合計 } \\
\text { (対前年伸び率\%) }\end{array}$ & $\begin{array}{r}94,500 \\
(14)\end{array}$ & $\begin{array}{r}107,925 \\
(14)\end{array}$ & $\begin{array}{r}119,120 \\
(10)\end{array}$ \\
\hline
\end{tabular}

( 81$)$
以上を占めるが，実用化され統計に上ってくるポ リマーアロイの種類が多くなっていることがわか る.

表 2 には，ポリマーアロイの組合せのらち, ご ースポリマーが，エンプラ 8 種であるものををと めた。この表のます目 98 種のうち，約40\%が市場 で材料としての評価を受けはじめていることは， 驚くべきことではないだろらか。

一方，話題性が先行している割には，市場で大 きく育っているポりマーアロイの種類は少ないよ 5に思われる。その大きい原因には，用途ごと に，そしてニーザーごとに，ポリマーアロイ化に よる特徵を引出しながらきめ細かく対応した開発 が必要なため，研究コストが大きいと，少量多 品種生産を余儀なくされることなどが挙げられよ 5. 更に, 要求性能の向上のためのアロイ化に加 えて，新らたな機能性の付与をポリマーアロイ化 に求めるよらになってきていて，これらす量的に はまだ小さい用途である場合が多い，

しかし，最近開発されたポリマーアロイ群は， 主として自動車部品を中心に市場展開が図られて いて，その主なものには, PC/PBT, PC/PET, $\mathrm{PA} / \mathrm{PPE}$ ，非晶性 $\mathrm{PA} /$ エラストマー，PA/ポリオ レフィンなどがある。これらの中から，自動車内 外部品に採用がはじまってきており，ポリマーア ロイの大量消費へ向けての着実な歩みが出はじめ ているといえる5)。

\section{2 技術開発動向}

ポリマーアロイ化における大きな技術課題の一 つは, 非相溶な組合せの成分からのアロイ化に際 して，ポリマー分散相の大きさをコントロールし ながら安定化することである。エンジニアリング プラスチックは，通常は射出成形や押出し成形な どのように熱を加光て変形加工する方法によっ て，実際に使用する場合の形状に仕上げることに なる。この熱可塑性を持っているという点が，エ ンプラの工業的な存在価值の一つであり，加工コ ストを低く抑光ることを可能にしている，ポリマ 一アロイ化したエンプラにおいても，この加熱成 形を行らので，その際に特性の变化をもたらさな い上5に，各成分ポリマーの分散状態の安定化 が，技術上の重要な键なのである。

この解決方法として，界面の親和性を一定に保 ちらるコンパティビライザーの添加が行われてい

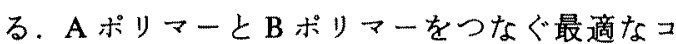


表 2 市場でみられるエンプラのポリマーフロイの組合せ

\begin{tabular}{|c|c|c|c|c|c|c|c|c|}
\hline $\begin{array}{c}\text { ペースポyマー } \\
(\text { エンプラ }\end{array}$ & $\begin{array}{c}\text { ポ } \\
y \\
7 \\
5 \\
ト \\
\text { (PA) }\end{array}$ & $\begin{array}{c}\text { ボ } \\
1 \\
7 \\
t \\
3 \\
1 \\
u \\
\text { (POM) } \\
\end{array}$ & $\begin{array}{c}\text { ボ } \\
リ \\
カ \\
1 \\
ホ 3 \\
\dot{x} \\
1 \\
1 \\
\text { (PC) }\end{array}$ & 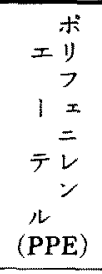 & 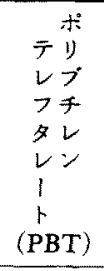 & 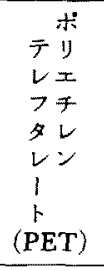 & 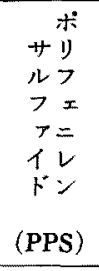 & $\begin{array}{c}\text { ボ } \\
1 \\
7 \\
1 \\
2 \\
1 \\
1 \\
\text { (PAR) } \\
\end{array}$ \\
\hline ポリオレフィン & (Q) & 0 & (2) & & 0 & & $\triangle$ & \\
\hline アイオノマー & (O) & & & & & (a) & & \\
\hline EPDM, PTMG & (O) & 0 & & & 0 & (O) & & \\
\hline ボリウレタン & & 0 & $\triangle$ & & $\mathrm{O}$ & & & \\
\hline $\mathrm{ABS}$ (AES, AAS) & 0 & & (2) & 0 & 0 & & & \\
\hline PMMA & & & $\mathrm{O}$ & & & & & \\
\hline PS采ポリマー & $\triangle$ & & (O) & (0) & 0 & & & \\
\hline PA & & & & 0 & & & $\triangle$ & \\
\hline $\mathrm{PC}$ & & & & & 0 & 0 & & \\
\hline PPE & 0 & & & & & & & \\
\hline PBT & & & (0) & $\triangle$ & & 0 & $\triangle$ & 0 \\
\hline PET & 0 & & $\mathrm{O}$ & & 0 & & & 0 \\
\hline PAR & 0 & & & & & 0 & 0 & \\
\hline
\end{tabular}

○：市暢実績定着， $\bigcirc:$ 本格上市品， $\triangle$ : 市場開発中

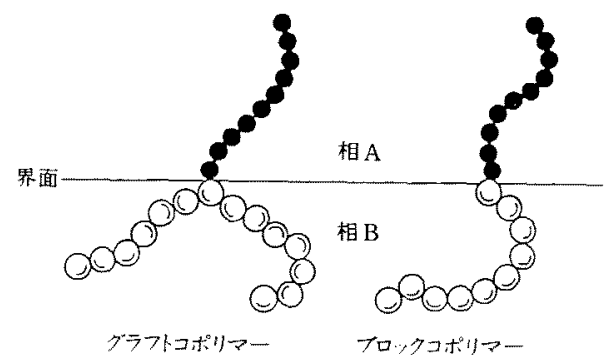

図 3 コンパティビライザーのモデル図6)

ンパティビライザーを見出すことによって次々と 新しいポリマーアロイが上市されている。

コンパティビライザーは，低分子化合物より は，ブロックコポリマー，グラフトコポリマーな どの高分子化合物が適している場合が多く，良く 引用されている図3のよらな界面を形成すること が理想的なのであろ56).

工業的に生産されているポリマーアロイでは， そのコンパティビライザーを明らかにしているむ のは少ないが，特許上からは，軟質成分を含さブ
ロックコポリマー, 即らエラストマー系の材料

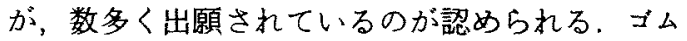
のより高付加価值な利用法とい之るであるら．

アロイ化のも5一つの大さな技術上の進展は， 押出機を用いて，化学反応をとるないながらポリ マーアロイを得る方法, いわゆるリアクティブプ ロセッシングの実用化に認められる7),8 . エンプ ラのポリマーアロイは，先にも記したように多品 種少量生産のbのも多く，きめ細かく切換え生産 ができる押出機タイプは，製造ブロセスとしての 洒值が大きい、リアクティブプロセッシングの利 点を列挙すると以下のよらになる。

(1)溶液を用いる反応に比べて設備費が少なくて すむ.

(2)溶剂や水など使用しないので，回收ュス ト，エネルギーコストが極めて少なくなる。

(3)ほとんどすべての熱可塑性ポリマーに適用で き，プロセスのはん用性，多様性の点で優れてい 万。

(4)反応させると同時に，物理ブレンド，フィラ 一とのコンパウンディングなどす行らことができ ๖.

( 82 ) 


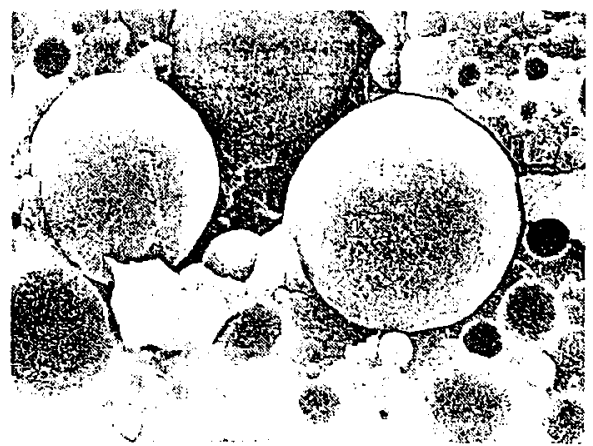

(a) PA6,6/PP

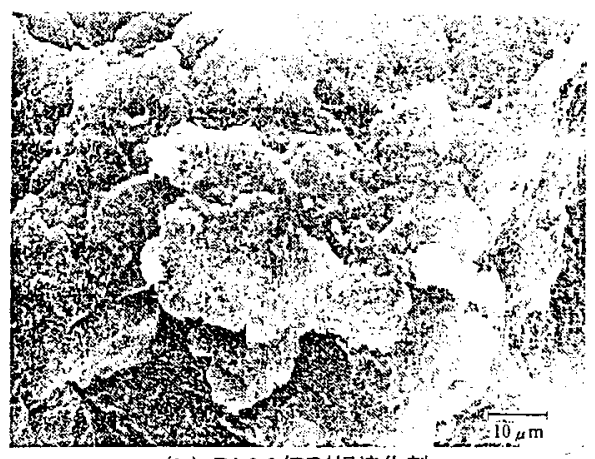

(b) $\mathrm{PA} 6,6 / \mathrm{PP} /$ 相溶化郕

図 4 PA6, 6/PP 系アロイ破断面の SEM 写真 ${ }^{10)}$

(5)反応副生物，不純物などの脱気処理もオンラ インで実施できる。

(6)品種切換えが, 容器型の反応槽などに比べて 格段に容易であり，多品種少量生産にも向く．

ポリマーフロイの解析技術む近年の進歩は著し (、9).ミミクロ相分離構造を直接観察する方法とし て，電子影微鏡の応用が広がっている. 主に破断 面の凹凸を観察して分散粒子の大きさや界面の接 着の様子を判断するのに用いるのが走査型電子顕 敨鏡(SEM)であり，試料の前処理にやや経験を 要するが簡便な手段とい党る．SEMによる観察 の例を図4 亿示す10).PA/PP系アロイのコンパ ティビライザーの効果が良くわかる，分散粒子が 0.2 ミクロン以下になると SEM では限界になる ことが多い，試料から超薄切片を切り出して観察 する透過型電子顕微鏡(TEM)が，上り微細な分 散き界面の状況を詳細に判断するのに用いられ る.オスミウム酸による染色ばかりでなく，種々 の電子線に対するし中閉性をつける手法が開発さ れて，PA，ゴム，ポリオレフィン，PPEなどを
区別できるよらになっている．モルホロジーの解 明には，その他に，光学顕微鏡，位相差顕徽鏡， 光散乱法, $\mathrm{X}$ 線小角散乱法, $\mathrm{X}$ 線回折などが使わ れる。

固体物性からのポリマーアロイの解析には, 最 も手軽で情報量の豊富な DSC が多く用いられ， $T_{g}$, 結晶化特性, 熱特性がしらべられている， $T_{g}$ の測定には，屈折率法, ディラトメトリー法, TOA 法などがある. 力学緩和もポリマーアロイ を構成するポリマーの鎖の動きをみるために多用

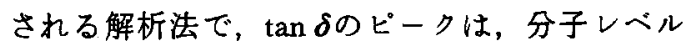
での相互作用の大きさについての判断に極めて有 用な情報を提供する.

ポリマーアロイは成形した場合に, バルクの組 成と表面の組成に差が出ることがしばしばあり， また表面付近に組成の傾斜があることもある。 XPS (X線光電子分光) や SIMS (二次イオン質量 分析)で，こ5した成分ボリマーの偏在を解析で きるようになってきている11)。

異種高分子間の相互作用を知ることや，それら が形成する界面の厚みを測定することはかなり難 しい，固体状態の FT-IR や固体高分解能 NMR による方法が報告されはじめている.

ポリマーアロイの赛用物性評価は, エンプラと しての用途に応じてさまざまであり，後の各論に 記した特性から読み取ってほしい、ポリマーフロ イ化に際して期待される実用物性の向上には，耐 衝撃性の向上, 耐熱性の向上, 成形加工性の改 良, 外観の向上, 制電性の付与, 難燃性の付与, 摩耗特性の向上, 塗装性·接着性の向上, めっき 特性の付与などが含まれ，限りなく広い。

ポリマーアロイ化で，まず第一にエンプラに付 与された特性は，耐衝撃性であった。はん用プラ

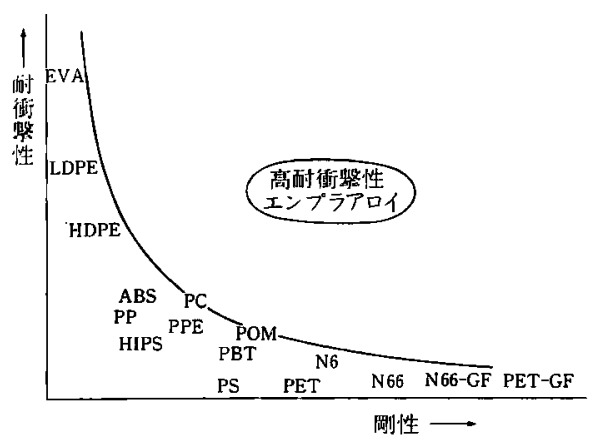

図 5 エンプラフロイの第一世代(耐衙撃性) 


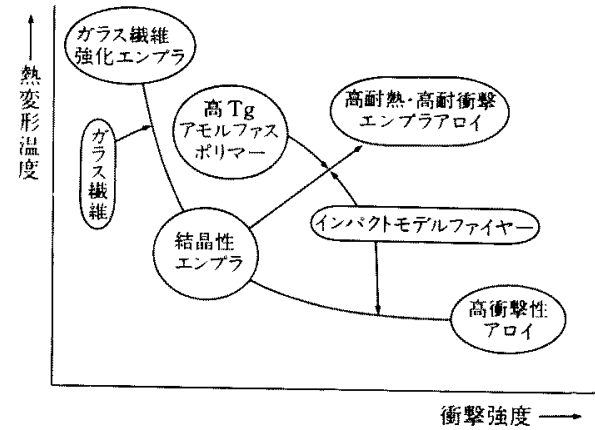

区 6 エンブラアロイの第二世代(耐熱，耐衝撃性 の付与)

に比べて高い剛性を持つェンプラ群も，耐衝撃性 が低くもろいものが多い，図 5 に示すよ5に，エ ンプラの剛性をなるべく保って衝撃性を上げる手 法が，第一世代と呼ばれている。

結晶性のエンプラは，ガラス緎維などのフィラ 一補強で高い耐熱温度が得られる。耐衝撃性の土 ンプラアロイは, インパクトモディフォイヤーの 添加で耐熱温度が低下している. 第二世代と呼ば れるェンプラのポリマーアロイは，高耐熱性と高 耐衝撃性を兼福える材料で，インパクトモディ ファイヤーとガラス転移温度 $\left(T_{g}\right)$ の高いポリマー とを併用した三成分系で構成される. 高 $T_{g}$ のア モルファスポリマーの働らきは有機フィラーとし てであり，PPE，PC，PARなどが有用に使われる といわれている。この働きを模式的に示したのが 図6である。

\section{3. ポリマーアロイ各論}

3.1 ポリアミド(PA)系ポリマーアロイ

アロイ化用素材としてみた場合のPAには，次 のような特催がある。

(1)勒性に優れているらえに, 他の素材と配合し うる割合の範囲が広い

(2)結晶性であり，耐薬品性と成形加工時の安定 性とに優れる。

(3)アミノ基，カルボキシル基を持つなど，末端 の反応性に富み, アロイ化に際して必要な化学反 応による变性がしやすい。

(4)共重合など主鎖の変更も比較的容易である。

これらを活かしつつ，ポリアミドの久点を他素 材で改良することができるので，広い範囲のポリ マーアロイが得られている、ポリマーアロイが脚

\begin{tabular}{|c|c|}
\hline メーカー & 主要銘柄 \\
\hline 旭化成 & レオナ 4300 \\
\hline デュポンジャバン & ザィテル ST801 \\
\hline 三菱化成 & ノハミミト ST120 \\
\hline 東レ & UNT121 \\
\hline 宇部興産 & $\mathrm{UBE}$ ナイロン10181 \\
\hline ユニ & ユニチカナイロン $\mathrm{EX} 1020$ \\
\hline 三井石油化学 & MCX-QA5030 \\
\hline チッソ & エンプナイト $\mathrm{H} 200 \mathrm{~B}$ \\
\hline BASF & Ultramid B3L \\
\hline Du Pont & Zytel ST801, ST901 \\
\hline Allied & Capron 8250 \\
\hline Enser Werke & Grilon A28NY \\
\hline Nylon Corp & Nycoa 1693 \\
\hline
\end{tabular}

表 4 PA とPPEとのアロイ

\begin{tabular}{ll}
\hline \multicolumn{1}{c}{ メーカー } & \multicolumn{1}{c}{ 主要銘柄 } \\
\hline 旭化成 & ライネックスザイロンA \\
$\mathrm{GE}$ & Noryl GTX600 \\
東レ & PPA-263 \\
三菱油化 & レマロイ \\
三菱ガス化 & ユビェース NX7000 \\
住友化学 & フートリーX19S \\
Borg Warner & Prevex S33 \\
BASF & Ultranyl KR4510 \\
\hline
\end{tabular}

光をあびるよらになったのは，1976年にデュポン 社が発表したスーパータフナイロンによってであ る. 無水マレイン酸変性したポリオレフィン系エ ラストマーとポリアミドとの反応は古くから知ら れていたが12)，コンパウンディング技術と結びつ けてスーパータフ化に成功したと伝えられてい る. 市販されているポリアミドとポリオレフィン とのアロイの代表銘柄を表 3 にまとめて示した。

スーバータフ化は，物性のバランス上，耐熱性 を儀性にしていることになる。一般的説明を図 6 に示していたよらに，PAに批てて、インパクト モディファイヤーとしてのボリオレフィン成分と ともに，高 $T_{g}$ のアモルファスポリマーである PPEを耐熱性向上成分として併用することによ り，耐衝撃性を兼视備えたポリマーアロイが得ら れるよらになった，GEヨーロッパ社が自動車外 板向けニーザーと共同開発したNoryl GTXを皮 切りに，各社から発表されている代表銘柄を表 4

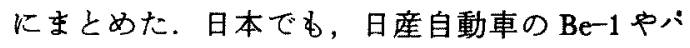


表 5 PA 系ポリマーフロイの代表的物性（成形直後）

\begin{tabular}{|c|c|c|c|c|c|c|}
\hline & 項 & & 单 位 & $\begin{array}{l}\text { コントロール } \\
\text { ナイロン } 66\end{array}$ & $\begin{array}{l}\text { 酎衝撃性 } \\
\text { ナイ }\end{array}$ & $\begin{array}{c}\text { 高耐熱·耐衝撃性 } \\
\text { ナイロ }\end{array}$ \\
\hline & 張 強 & さ & $\mathrm{kg} / \mathrm{cm}^{2}$ & 830 & 480 & 460 \\
\hline & 張 伸 & び(破断) & $\%$ & 60 & 82 & 140 \\
\hline 曲 & $け ゙ \quad$ 強 & さ & $\mathrm{kg} / \mathrm{cm}^{2}$ & 1,200 & 690 & 800 \\
\hline & 壮弾 性 & 率 & $\mathrm{kg} / \mathrm{cm}^{2}$ & 29,000 & 18,200 & 19,500 \\
\hline \multicolumn{3}{|c|}{ フイデット衝璧強さ $\left(23^{\circ} \mathrm{C}\right)$} & $\mathrm{kg} \cdot \mathrm{cm} / \mathrm{cm}$ & 4.5 & 130 & 70 \\
\hline & (ノッf付) & $\left(-30^{\circ} \mathrm{C}\right)$ & " & - & 22 & 25 \\
\hline \multirow[t]{2}{*}{ 熱 } & 変 形 温 & 度 ( 4.6 kg 荷重) & ${ }^{\circ} \mathrm{C}$ & 230 & 213 & 170 \\
\hline & & $(18.6 " \prime)$ & ${ }^{\circ} \mathrm{C}$ & 70 & 61 & - \\
\hline
\end{tabular}

オのフェンダーに，オンライン焼付け塗装ができ る材料として採用されて注目を集めている5).

PAKここしたアロイ化を行った場合の代表 的な物性がどのように変化するかる表 5 に一括し て示した。

PAの欠点である吸湿性を改良するためのポリ マーアロイ化は，PP，PBT，PETなどを混ぜる方 法が各社から発表されている゙．

RIM ナイロンもポリマーアロイの典型例であ り，米国の Monsanto 社が開発した「NYRIM」 は、オランダの DSM 社に移って央用化が進展し ていると伝えられている。各社からナイロンの RIM 化が発表されている。

3.2 ポリアセタール(POM)系ポリマーアロイ POM は，ホモポリマー，コポリマーともに， あまり多くのポリマーアロイは知られていない。 POM の特性である高潤滑性を更に向上させるた めに，POM との親和性はないが，シリコーン油 やPTFEを添加するアロイ化は，実用にも供さ れている。こ饴はボリマーフロイとはいっても 添加される第二成分の量はごく少ない範囲である.

POM の耐衝撃グレードは，デュポン社のデル リン500 Tが有名で，熱可塑性ポリウレタンとの ボリマーアロイである。各社の酎衝撃性 POM ア ロイをまとめて表 6 に示す。その他に，ポリブタ ジェン、アクリルゴム，グラフト化合成ゴム，ポ リオレフィン, PTMG, EPコポリマーなどあ POM の衝撃性向上に利用されている.

POMのメッキグレードも，ボリマーアロイの 手法を活用して作られている13).

3.3 ポリカーボネート(PC)系ポリマーアロイ PCをポリマーアロイ化する目的は，成形時の 流動性を向上させること，及び，耐薬品性を改良 することであって，PCの欠点を克服することが
表 6 耐衝撃性 POM 系アロイ

\begin{tabular}{|c|c|}
\hline メーカー & 主要銘柄 \\
\hline 旭化成 & テナック SN456 \\
\hline ポリブラスチック & ジュラコンSU25 \\
\hline デュポンジャパン & デルリン $500 \mathrm{~T}$ \\
\hline 三菱ガス化学 & FU2025 \\
\hline 三夌油化 ジディッシュ & N2640X \\
\hline Höchst & Hostaform S \\
\hline BASF & Ultraform N2640X \\
\hline
\end{tabular}

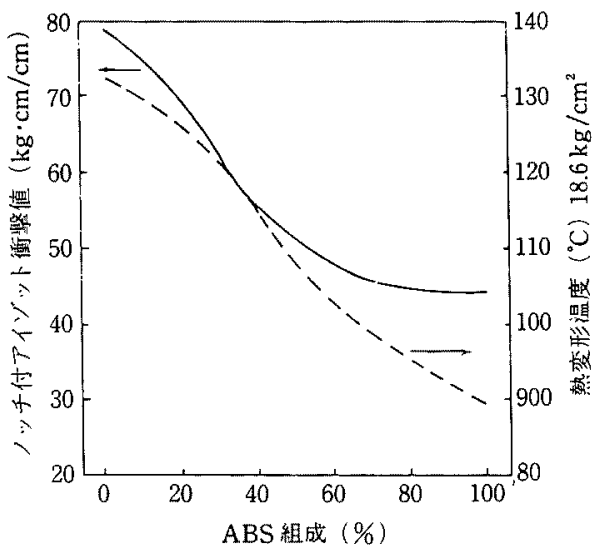

図 7 PC-ABS 組成と物性 ${ }^{14)}$

主要な狙いである。

このためのアロイ化の相手としては，ABSゃ PBTが良く知られている。

む5一つ, PCのアロイ化の方向があり，PC の特性に加えて，更に新しい機能を付与すること を狙いとしている，めっき性，摩耗特性，特殊外 観(マーブル調)などの特性をるつ材料が PC をべ 一スに作り出されている。

工美的に奏用化されている PC 系ポリマーフロ 
イは，PC/ABSとPC/PBT がほとんどである.

PC/ABS 系は，分子レベルをでの相溶性はな いが，いくらかの相互作用が認められていて，図 7 に示すよ5に ${ }^{14)}$ ，成分ポリマーの組成比と，熱 変形温度及びアイゾット衝撃強度は，ほぼ直線的 に変化する.こうした物性のバランスから，実用 的には PC/ABS の組成が50/50前後の材料が選ば れている，PC/ABSアロイの特徵は，全体の物 性ハシランスが良くとれていることに加えて，流動 加工性に優れ，耐衝撃强度の厚多依存性やノッチ 感度がPCに比べて大幅に減少して使いやすくな っている、 $-30^{\circ} \mathrm{C}$ 前後の低温衝撃性を必要とす る場合には，第三成分としてェラストマーを添加 するのは他のポりマーアロイと同じ考え方による.

耐候性を要求される用途が拡大するにつれて， ABS 中のポリブタジェンに代えて，フクリルゴ ムや EPDMを使った, AAS, AESとPCとのア ロイが実用化されてきている。

PC/ポリエステル系アロイは, PC/PBTがほ んどであり, 熱安定性, 酎衙撃性, 耐薬品性, 耐 溶剂性のバランスのとれた材料として自動車部品 中心に需要が拡大している，PC/ポリエステル系 フロイが1981年に，PCバンパーとして，いすず 自動車に採用された時は業界の注目を集めた：そ の後, 米国の GE 社のXENOY (PC/PBT ア口 イ)が，欧州車のパンパーに広く実績を挙げてお り，日本国内一も売込みをはかっている。

PC/ポリエステル系フロイが, 米, 欧で自動車 パンハーを中心に量的に多く使用されているのに 比べれば，日本の市場への展開はまだこれからと いえる. 開発中の部品は，バンパー,ドアハンド ル, メーターカバー, ラジェーターグリル, ラン プまわり，カークーラー吹出口などで，主として 自動車外装向けである。

また，PC/ポリエステル/エラストマー系によ る用途開発も一部で行われておりこれらは低温 衝撃強度を維持するためと相溶性を高めるためと いわれている。

各社により上市されている材料の大半はカスタ マーグレードで, 主として自動車部品メーカーと ポリマーアロイ材料メーカーのタイアップにより 開発が進められている。したがって，PC/ポリェ ステルの配合比率るグレードによりまちまちであ る。

$$
\mathrm{PC} / \text { エストマー系アロイは, ハイフロータイ }
$$

プの PC の低温衝撃強度を保持すること及び，ア イシット衝撃強度の厚み依存性やノッ千感度を改 良することを目的に開発されている，PC/ポリオ レフィン系アロイす同様の目的で作られている.

PC/PMMAはアロイ化すると成形時にミク口 な層状分散を示して独特の真珠光沢を出す。家 電, 化栍品容器などの装飾用途に使用されている.

PC/PA アロイは，また㬰用化例は聞かないが， 米国で良い相溶化剛が見出されたと発表されてい $3^{15)}$.

3.4 ポリフェニレンエーテル(PPE) 系ポリマ 一アロイ (16), 17)

PPE は, 1964年の上市後 1 年半を経て, 成形 加工性を大幅に改良したボリマーアロイの 「Noryl」が発表されて実用途が急速に桩大したエ ンプラである18)。それ以降，PPEはその99\%以 上がスチレン系ポリマーとのポリマーアロイとし て使われている珍しいポリマーである，PPEは， 耐熱性, 電気特性に優れ, その上難然化しやすい といら特徵があるが，流動性，加工性の不足か ら，射出成形品，押出成形品などの中の成形ひず みを除くことが難しい.PPEの鎖と分子レベル で均一に混合しらるポリスチレン(コム補強ポリ

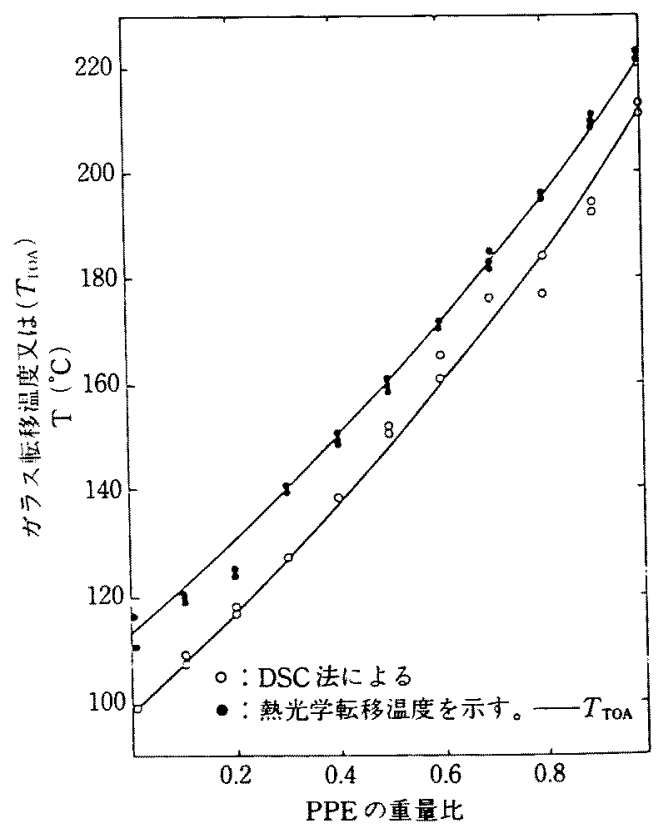

図 8 PPE/PS系アロイのブレンド比とガラス転移 温度) 
表 7 変性 PPE の需要（トン/年) ${ }^{16)}$

\begin{tabular}{|c|c|c|c|c|c|c|}
\hline & & 59年 & 60年 & 61年 & 62年 & 63年 \\
\hline 国 & 内 & 41,500 & 43,700 & 48,200 & 53,300 & \multirow{2}{*}{ （推定） } \\
\hline 輸 & 出 & 3,600 & 3,200 & 3,200 & 4,200 & \\
\hline 合 & 至 & 45,100 & 46,900 & 51,400 & 57,500 & 64,000 \\
\hline
\end{tabular}

表 8 变性 PPE の生産能力（トン/年) ${ }^{16)}$

\begin{tabular}{lcc}
\hline メーカー & 工場 & 63 年現在 \\
\hline 日本ジーープラスチックス & 栃 & 50,000 \\
旭化成 & 千 葉 & 20,000 \\
三菱ガス化学 & 四日市 & 10,000 \\
日本ボリエーテル* & 四日市 & 10,000 \\
\hline
\end{tabular}

* 三菱油化と住友化学の合弁

スチレンで使らことが多いによって内部可塑化 が実現して加工性が大幅に向上するのがこのポリ マーアロイの特徵である. 図 8 は, PPE/PS 系ア ロイのブレンド比率とガラス転移温度との関係を 示すもので，双方のポリマーの分子レベルでの分 散を示している2)。このことから，PS系ポリマ 一とのアロイ化では，実使用温度 (HDT) を自由 に，しか子連続的にコントロールすることがで き，技術上，商品開発上の大きな特徵となってい、 る.スチレン系ポリマーとの多様なポリマーアロ イが一つの商品群となっているので,これらをま
とめて変性 PPE と呼ばれている。変性 PPEは, ニーザーニーズに対応したグレードがそれぞれ開 発できることから，エンプラ群の中では異常にグ レード数の多いポリマーになっている19).

変性PPEとしての日本の市場における需要実 績と生産能力とを表 7, 表 8 亿示す16).

PPE は，上市直後から数多くの他樹脂とのポ リマーアロイ化が提案され，特許化されたことで も有名であるが，変性 PPE(PS 系アロイ)の他に, $\mathrm{ABS}, \mathrm{PA}, \mathrm{PBT}$ などとのポリマーアロイがすでに 提供されている.

アクリロニトリルを共重合させている ABS 樹 脂は，スチレン系ですPPEとの均一なポリマー アロイを作ることはできない，したがって，アロ イ化には技術上の克服すべき課題も多い，PPE/ ABS 系のアロイでは，光沢改良のLシリーズ， 耐油性改良のYシリーズ，及びメッキグレード が実用的商品として上市されている20).

PA とのポリマーアロイは，PPEの高いガラス 転移温度を生かした有機フィラーとしてPA 補 強するタイプのるのが主流になっている。(PA の項参照)，ガラス瀻維で補強した PPE/PA 系ア ロイは、コネクター、スイッチリレーケース， プリンターキャリッジ等, グリース類などに接す る電気・電子用途等に広く活用されている. 表 9 に，その代表的な物性を示す16)。

表 $9 \mathrm{PPE} / \mathrm{PA} / \mathrm{GF}$ 系フロイの一般物性 ${ }^{16)}$

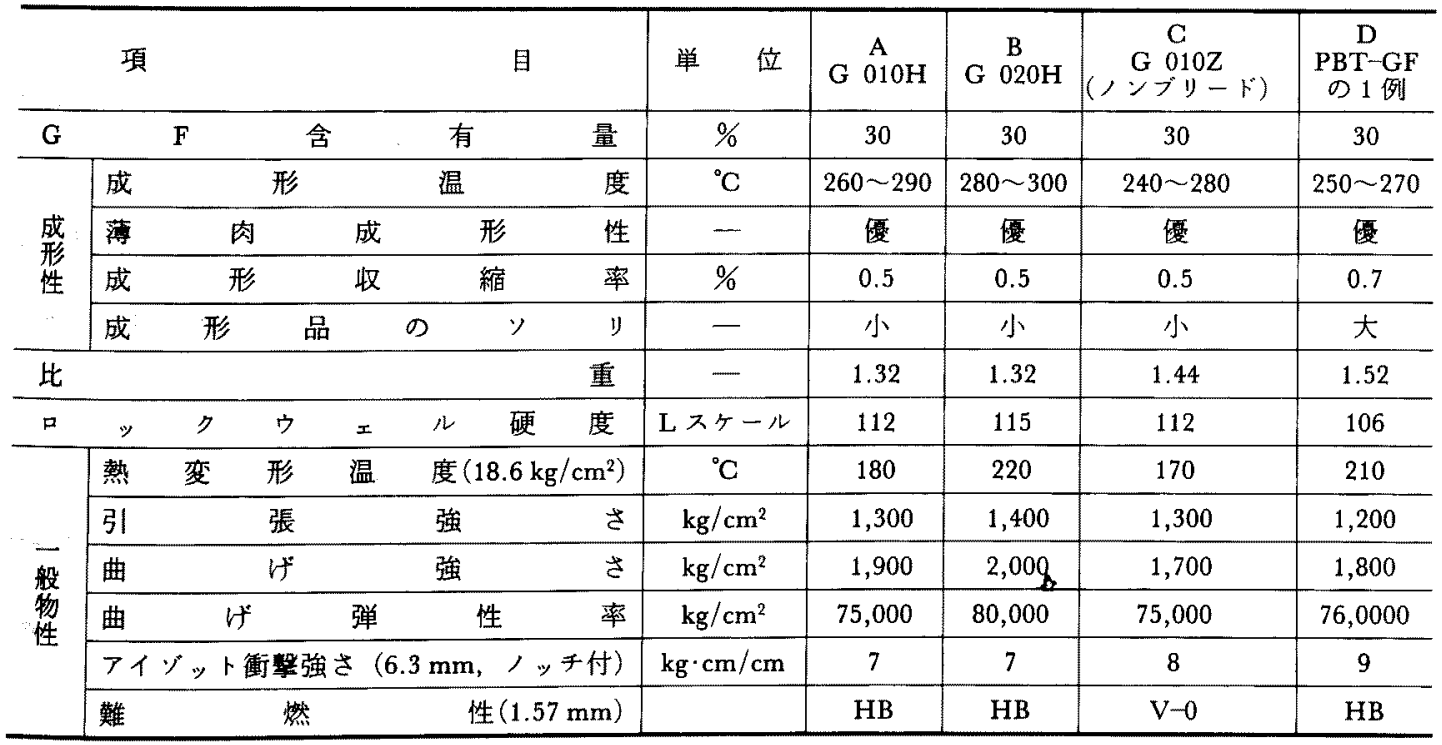


SBS系ブロックエラストマーとPPEとのポり マーアロイは、数々のユニークな挙動を示すため に学術論文が多数出されている21),22)が，内容に ついては省略する。

飽和ポリエステルとPPEとのアロイ化は， 1988年以降，国内外の多数の会社がら特許が出願 されているが，1987年のSAEにタイミングを合 わせて, GE 社から， PPE/PBT/×ラストマーの アロイが，自動車外板向けとして発表された ${ }^{23)}$. これは，PPE/PA/エラストマー系アロイによる 外板の持つ欠点，すなわち，吸湿による寸法変化 及び物性の低下を克服し，低吸湿性と高耐衝撃性 を兼備した材料であるといわれている。

PPS とのポリマーアロイは，化学構造の類似 性の割には近年まで知られていなかったが、コン パティビラィザーの工夫やフィラー類の添加で相 乗作用の特徽を引出す工夫によって，特許が数多 く出されるよらになってきた24).

\section{5 ポリエステル系ポリマーアロ1}

ポリエステル系のポリマーアロイは，数の上で は多様な組合せが上市されているが(表 2 参照)，

実用化されていて量が多いのは，ポリエステル同 士のアロイである PBT/PET と，エラストマーに よるタフネス改良(特にABSとのアロイ)の二種 類といえる.

$\mathrm{PBT} / \mathrm{PET}$ アロイは, ガラス繊維強化に際して のソリ発生を少なく抑える効果及び，PETを加 えることより成形品外観のうち光沢が向上するこ との二点が大きな改良点といるる。配合割合が自 由に変えられるアロイであるために，一般には PBTのグレードの中に埋没して，詳細を明かさ ないメーカーが多い. 表10に示す 3 社が, PBT/

表10 PBT/PET系アロイ

\begin{tabular}{|c|c|}
\hline$x-s-$ & 主 要 銘 柄 \\
\hline 帝 & PCT 樹脂 C5330 \\
\hline $\begin{array}{l}\text { 三菱 化 成 } \\
\text { ポリブラスチック }\end{array}$ & 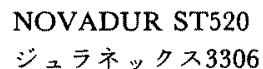 \\
\hline
\end{tabular}

表11 PBT/ABS系アロイ

\begin{tabular}{ll}
\hline \multicolumn{1}{c}{ メーカー } & \multicolumn{1}{c}{ 主要銘柄 } \\
\hline 東レ & UX100,150 \\
ダイセル化学 & ノバイ B シリーズ \\
バイエル (西独) & POCAN \\
\hline
\end{tabular}

PETアロイとしてク゚レードを区別している。

PBT 樹脂は，ポリエステルの中では勒性には 優れているが，衝撃強度に関してはノッ千感度が 大さいのが久点である。この耐衝撃特性を改良す るために，ポりオレフィン，ブチルゴム， $\mathrm{EPDM}$ ，ポリイソブチレン，アクリルゴム， ABSなどとのアロイ化が行われている.

$\mathrm{PBT} / \mathrm{ABS}$ アロイは，その中でも新しい材料で あり，昭和62年頃から市場での評価が始まってい る.その商品例を表11に示す。低ソリ，酎衝撃性 に加卡， GF 強化材料では酎熱性が200 20 以上 設計されている。

難然 $\mathrm{GF}$ 強化 $\mathrm{ABS}$ 樹脂の上位にランクされる 材料で, OA 機器分野のシャーシー, フレーム, ファンなどへの開発が活発に行われている。

\section{6 ポリフェニレンサルファイト(PPS)系ポ リマーアロイ}

PPS は，これまでGF 又は無機フィラーを多量 に含も複合素材として市場を開拓してきている。 ポリマーアロイ化は, PPS/ポリアリレート (PAR)が本格上市されている以外は試作段階と 考えてよい.PPS/ポリオレフィン，PPS/PA, PPS/PBT, PPS/ポリサルホンなどが，開発中の 材料としてユーザーテストに向けられている。

\section{4. おわりに}

ここまでに採り挙げなかった数々のエンプラ， 耐熱エンプラにおいても，ポリマーアロイの開発 は着実に進んでおう，近日中にまだ新しいニース が登場してくる可能性も高い.

各論の実際の組合せ例です，しばしば指摘した よらに，ポリマーアロイ化は，材料メーカーとニ 一ザーとが，特定の目的に合わせた共同作業でカ スタムグレードを作るといら形で実用的開発が進 められている。それだけにこ㞦から女材料メ一 カーにとっての多品種少量生産といら壁とも戦い ながら，先端産業用途を支える「新材料」が次々 に生み出されていくと期待される25).

\section{引用 文 献}

1) 伊澤槙一：ファインケミカルテク/ロジー推進つ ッヒンブリー'88, 要旨集 2-21(1988)

2) Shultz, A. R., Gendron, B. M.: J. Appl. Polym. Sci., 16, 461 (1972)

3）伊澤槙一：化学工業, 34(5), 400（1983）

4) 井上隆, 市原祥次：ポリマーアロイ，共立出版 


\section{(1988)}

5）東レリサーチセンター編：自動車材料の新展開, (1988)

6) 伊澤槙一：先端材料の新技術, p. 75 , 化学同人 (1987)

7) Bartila: Polym. Eng. Sci, 27(16), 1216 (1987)

8) Tucker, C. S., Nichols, R. J.: Plastics Eng. No.5, p.27 (1987)

9）西 敏夫：機能材料， 8, (1), 16 (1988)

10）角五正弘：同誌8，(1)，84（1988）

11）三木哲郎：化学々工業，42，(5)，837 (1989)

12) Ide, F., Hasegawa, A.: J. Appl. Polym. Sci, 18, 963 (1974)

13）特開昭57-168936

14）本間精一：機能材料，8，(1)，40 (1988)

15) USP 4, 782, 114 (1989), Perron, P. J. Com- palloy'89 要旨集, p.263 (1989)

16）伊澤槙一，浜田稳：機能材料，8，(1)，68 (1988)

17）伊澤槙一，原田洋：ポリマーブレンドの製造と応 用, シーエムシー (1988)

18) Modern Plastics, Dec, p.95 (1964), SPE Journal, 22 (5) $53(1966)$

19) Wood, A. S.: Modern Plastics, July, p.38 (1986)

20）旭化成力タログ及び技術凟料

21) Tucker, P. S., Barlow, J. W., Paul, D. R.: Macromolecules, 21, 1678 (1988), ibid, 21, 2794 (1988)

22) Tucker, P. S., Paul, D. R.: Macromolecules, 21, (9), 2801 (1988)

23）可知 博：工業材料，35，(6)，p. 1 13（1987）

24） 日特公昭 $56-34032$ など多数

25）伊澤槙一：プラスチック事典(宮坂啓象編) 朝倉書 店 (1989)

\section{会員増加に御協力を!}

本会では, 会員の増加運動を積極的に行っております。知合いの方，新入社員，学生の方で未入 会の方が怙られましたら，ぜひ入会を御勧誘下さいますよう㹉願い申しあげます，入会申込書は 8 月号添付のものを御利用いたたくくか記あてご請求下されば，早速お送りいたします。

事務局 $\mathbf{T} 107$ 東京都港区元赤坂1-5-26 社団法人 日本ゴム協会会員係 電話 $03 \quad$ (401) 2957 